Dept. of Animal Hygiene,

Faculty of Vet. Med., Assiut University,

Head of Dept. Prof. Dr. A.A. Ismail.

\title{
SOME MANAGEMENT TECHNIQUES FOR REFERDING OF ANIMAL AND POULTRY WASTE \\ (With Two Tables)
}

\section{By \\ REEM M. DOSOKY; M.A. SOBIH and NABILA GAZIA (Received at 20/2/1989)

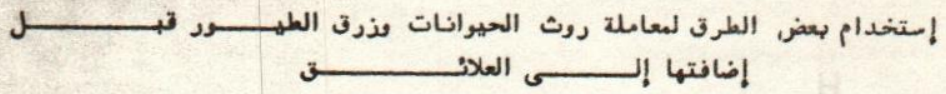

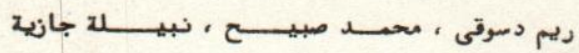

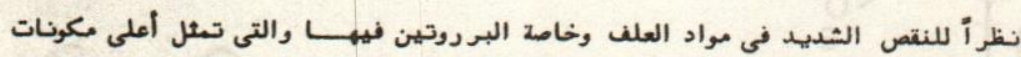

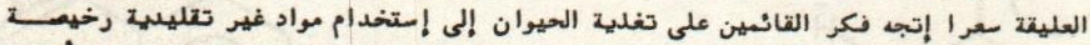

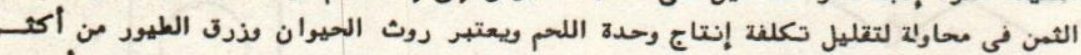

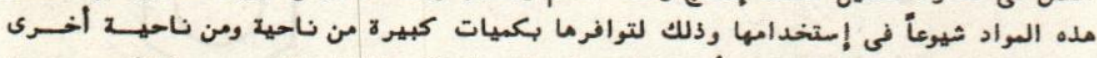

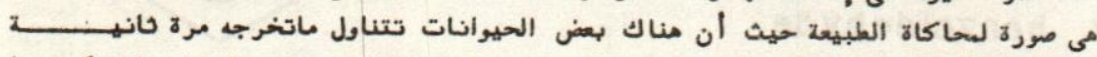

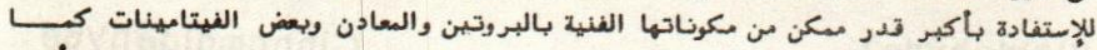

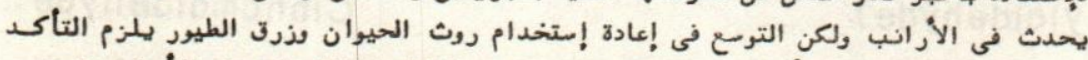

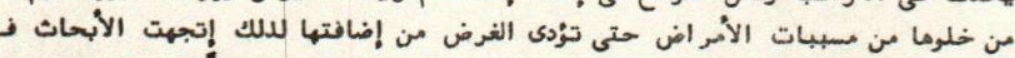

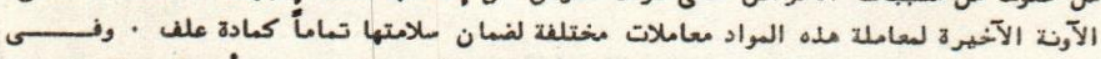

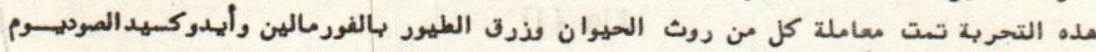

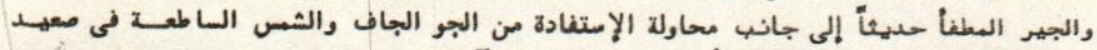

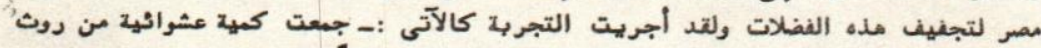

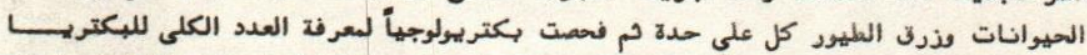

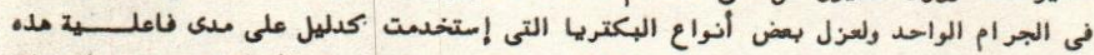

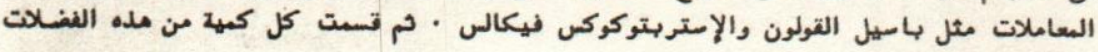

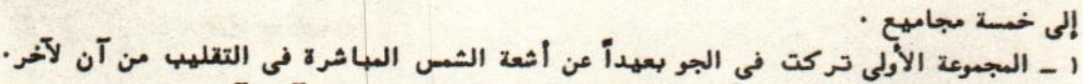

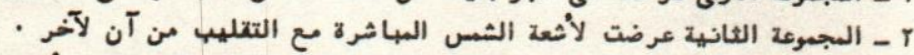

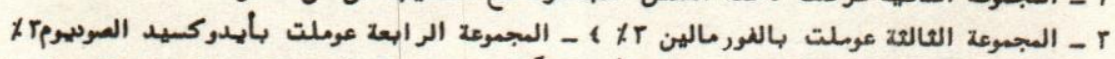

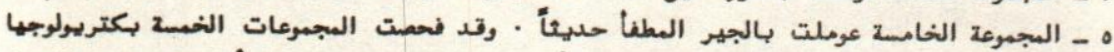

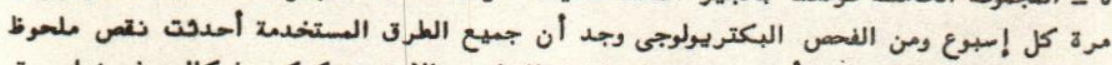

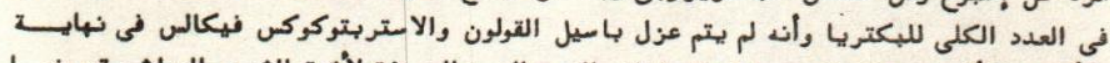

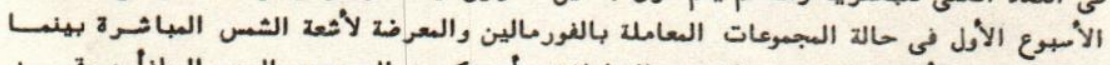

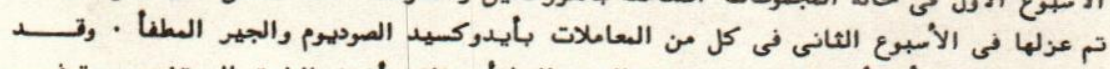

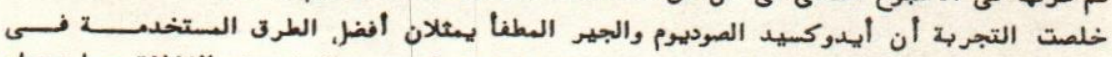

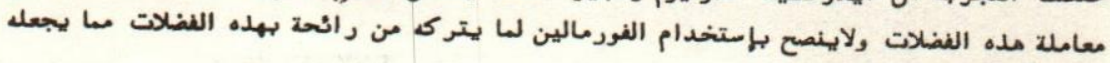
غير مقبولا كعادة علـ ملفه 


\section{REEM DOSOKY, et al.}

\section{SUMMARY}

Animal wastes represents a vast reservoir of cheap nutrients, particularly for ruminants. In most countries, waste, particularly from poultry, is easily collected, as it is and concentrated in small areas. Feed costs for dairy or beef cattle usually represent $50-80 \%$ of the total production costs this can be reduced to $20-40 \%$ by utilizing animal and poultry wastes as supply source of protein, minerals and other nutrients.

As the chemical composition and thus the nutritive value of wastes depend on many factors, of which waste management contributes major part, many different management techniques have been tried to ensure the safety of these wastes as feed.

The results achieved in this study indicate that all methods used for processing the animal and poultry wastes cause marked reduction of the total viable count. The indicator bacteria is completly inhibited at the end of the 1st week of exposure to formalin and sunlight, but they remain viable till the end of the 2 nd week of exposure to sodium hydroxide and slaked lime.

\section{INTRODUCTION}

Animal waste management is rapidly becoming one of the major environmental concerns in the world. Because of the enormous amount of animal waste generated, many different management techniques have been tried, of which especially promising is the refeeding of animal wastes. The value of animal waste as feeds appear to be more superior to their other uses as it will result in reducing feed cost and a lower price of animal produsts, in addition, it contributes to self-sufficiency in protein, phosphorus and other expensive nutrients inruminant rations. The most valuable constituent of animal wastes is the nitrogenous fraction represented by protein and non protein nitrogen.

Poultry wastes are usually high in nitrogen content, avaraging 28\% (EL-SOBBAN, et al. 1970; FONTENOT, et al. 1971). However uric acid, the main non protein nitrogenous compound in poultry wastes could be utilized efficiently by rumen microbes. Satisfactory performance was obtained when animal and poultry wastes are fed to farm animals and the taste of meat, milk and eggs has not been adversely affected (NOLAND, et al. 1955; EL-SOBBAN, et al. 1970; BULL and REID, 1971). ABD-ELLAH (1986) reported that additionof poultry waste to ruminant rations improve the digestibility of different nutrients while cattle waste shows no bad effects on ration digestibility and utilization, he also added that poultry wastes and cattle excreta could be used up to $27 \%$ and $14 \%$ respectively of the whole ration for sheep.

Assiut Vet.Med.1. Vol. 22, No. 43,1989. 


\section{MANAGEMENT OF ANIMAL WASTES}

Livestock wastes contain most of the same classes of chemical compounds found in feeds. Some form of treating the wastes for refeeding is desirable to make nutrients more available, to control adours, insects and to control disease problems. Also refeeding treated wastes offer the possibility of reducing the amount of new feed required.

Processing of animal wastes prior to refeeding is very important since harmful organisms may be destroyed with proper treatment (FONTENOT and WEBB, 1974; BHATTACHARYA and TAYLOR, 1975; FONTENOT and WEBB, 1975; MCCASKEY and ANTHONY, 1979). All listed number of processing methods that have been used for eliminating pathogenic microorganisms including, heat, pelleting, chemical, fermentation and oxidation ditch aerobic liquid treatment.

There are many unanswered questions with regard to animal wastes as agent of disease transmission, and information on basic research is still lacking. Many pathogenic organisms are capable of causing disease in humans, livestock and poultry, have been isolated from animal wastes (U.S.D.A., 1957; SCHWABE, 1964). There are circumstances when animals are asymptomatic carrier for certain diseases which can infect and cause disease in other species (ADLER, et al. 1953). Microbial population in animal wastes is dependant upon many factors which may influence their multiplication. Several pathogenic organisms present in poultry excreta may affect other animals. Salmonella pullorum has been known to infect cattle, E. rhusiopathia produce infection in swine and birds; M. avium is capable of sensatizing cattle which react to mammalian tubercline (WILSON and MITES, 1964; DAVIS, et al. 1974). Several studies have been conducted for the isolation of pathogenic microflora in animal waste which may produce diseases in poultry as well as cattle, swine and sheep (NILO and AVERY, 1963; ALEXANDER, et al. 1968).

Many workers studied the effect of physical condition and storage of litter on bacterial population, they observed that moisture, $\mathrm{PH}$, temperature of storage exerted little influence on microorganisms densities (SCHEFFERELER' 1965 a,b, 1966; LOVETT, et al. 1971). SMITH (1955) reported that salmonella galinarium may be detected after 6 to 59 days in poultry droppings allowed to air dry. On the other hand, STRAUCH and MUCLLER (1968) stated that salmonella species in the manure destroyed within a period of 6 days in summer and after 26 days in winter. Although a potential disease problem due to bacteria in animal waste does exist, chemical, or physical treatments of the wastes should destroy these potential pathogens.

In a trial to study the influence of various disinfectants as well as physical treatments on bacterial populations and some pathogens in animal and poultry wastes, this work was done to ensure its safety as animal feed.

\section{MATERIAL and METHODS}

Lots of fresh cattle and poultry wastes were collected for chemical and physical treatment. Each type of manure was divided into 5 parts, two of them were spreaded 


\section{REEM DOSOKY, et al}

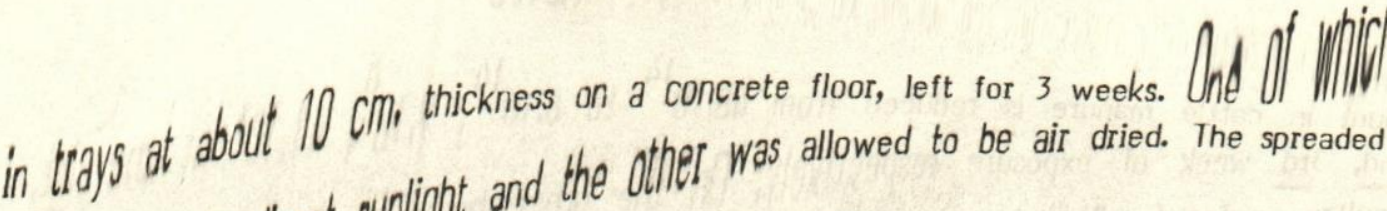

The other three parts were treated chemicaly. formalin $30_{0}^{\circ}(30 \mathrm{ml}$ for $1 \mathrm{~kg}$ of the waste). (30 $\mathrm{ml}$ for $1 \mathrm{~kg}$ of the Waste
slaked lime $(30 \mathrm{gm} / 1 \mathrm{~kg}$ of the waste).

The survivability of the bacteria in fresh, spreaded and chemically treated manure The survivability of the bacteria in fresh, spreaded and chemically (30 gm/
were detected by bacteriological examination of all groups at one week interval, accord-
ing to BAILY \& SCOTT, 1978; CRUICKSHANK, et al. 1980 as follows:

1 - Total colony count: One gram of each of the 5 groups was colony count.

One $\mathrm{ml}$ was taken from the emuls

2- Detection of indicator
2.1. Strept. Faecalis: Strept., faecalis (S.F.) broth was inoculated by the faecal sample and incubated at $37^{\circ} \mathrm{C}$ for $18-24 \mathrm{hr}$ Representative colonies were identified according culture characters and biochemical activities.

ated onto MaCconkey broth. The inoculated tubes Waste samples were inoculated onto A loopful from the enriched tubes was were incubated at $37^{\circ} \mathrm{C}$ for 24 hincubated at $37^{\circ} \mathrm{C}$ for $24 \mathrm{hrs}$. carried out on MaCconkey agar plate an growth characteristics and bioIdentification of pure chemical reactions.

3 - Estimation of moisture content:

of each of the experimental samples was estimated according to A.O.A.C. (1965).

\section{RESULTS and DISCUSSION}

Animal wastes to be fed should not contain pathogenic bacteria and toxogenic moulds, so treating animal waste before refeeding is very important to destroy harmful organisms.

Physical treatment especially solar drying is probably the oldest method of processing waste for refeeding, especially poultry excrement, as it has the lower moisture content than that of other livestock.

From table $(1 \& 2)$ it is shown that the exposure of cattle and poultry manure to air drying (indirect sunlight) cause reduction in tptal microbial count. The total viable count in poultry waste is reduced from viable $14.10,38.10^{3}$ at the 1st, 2nd, 3rd week of exposure 


\section{MANAGEMENT OF ANIMAL WASTES}

count in cattle manure is reduced llom $48.10^{14}$

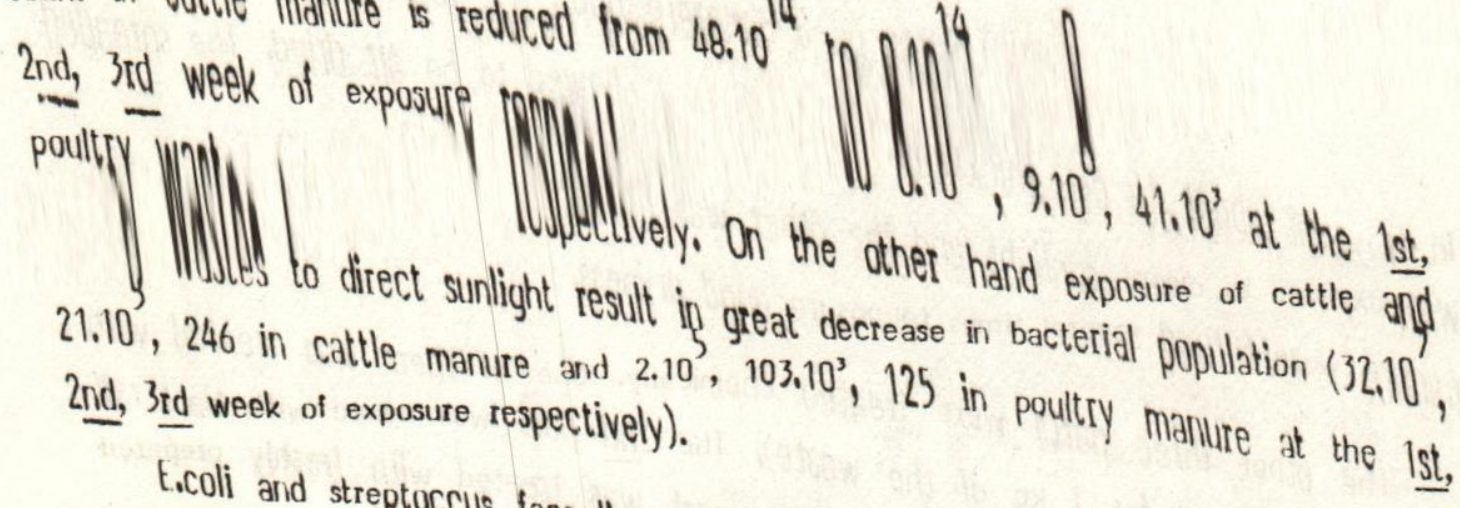

of exposure to direct and indirectis were not detected at the end of the second week sunlight E.coli is completely inhibited. It is at the 1st week of exposure to direct content of manure exposed to air is also evident from table 1, 2 that the moisture sunlight.

Treatment of poultry waste and animal manure by chemicals is important for destroying pathogens and it may improve its quality as feeds. From table $(1,2)$, it is evident that treatment of animal and poultry waste by formalin $3 \%, \mathrm{Na} O \mathrm{OH} 3 \%$ and end of the 3rd week of the greatly reduced the total viable count especially at the

E.coli and strept. faecalis were not detected at the end of the 1st week from adding formalin to cattle and poultry waste, but both organisms were completely inhibited after a period of three weeks from adding $\mathrm{NaOH} 3 \%$ to both types of manure. Cattle and poultry waste treated by freshly prepared staked lime gives results not differ from those obtained by sodium hydroxide treatment.

From the results achieved, one can concluded that treatment of animal waste by sodium hydroxide and lime are more satisfactory methods as they improve the quality of waste as feeds (SMITH, et al. 1969) however, the treated manure with formalin will be rejected due to its unpleasent smell.

\section{REFERENCES}

Abdella, A.M. (1986): The use of unconventional ration ingredients in feeding sheep. Ph.D. Thesis, Faculty of Vet. Med., Assiut University.

Adler, H.E.; H.A. Nelson and W.J. Stadelman (1953): A study of turkeys artificially infected with salmonella typhimurium. Amer. J. of Vet. Res., 14: 246.

Alexander, D.C.; J.A. Carrier and K.A. Mckay, (1968): Bacteriological studies of poultry litter fed to livestock. Con. Vet. J., 9: 27. Association of Official Agric. Chemisto (1965): Official Methods of Analysis 9th Ed.,
Washington, D.C.

Baily, W.R. and Scott, E \& G. (1978): Diagnostic microbiology A. text book for the isolation and identification of pathogenic microorganisms. The C.V. Mosby Comp.

Bhattocharya, A.N. and J.C. Taylor (1975): Recycling animal waste as a feedstuff. A review J. Anim. Sci., 41: 131, 1438-1457. 


\section{REEM DOSOKY, et al.}

Bull, L.S. and J.I. Reid (1971): Nutritive value of chicken manure for cattle. Proc. Internat. Sym on Livestock wastes. ASAE. Pub2 Proc. 271-297.

Cruickshank, R.; Duguid, I.P.; Mormion, B.P. and Swain, R.M. (1980): Medical microbiology 12th Ed. Vol. 11, reprented Churchill Sivingstone and Robert Stevenson Endinburg EHI 3 HF.

Davis, B.D.R.; Dulbecco, M.N.; Eisen, H.S.; Guisberg and W.B. Wood (1970): Microbiology Hoeber Medical division, Hayeer and Row bublishers Inc. New York.

El-Sobban, J.W.; Bratzier, T.A.; Tong, D.E.H.; Frcar and R.F. Gentry (1970): Value of processed poultry waste as a feed for ruminant. J. Anim. Sci., 31: 107.

Fontenot, J.P.; K.E. Webb; Jr., B.W. Harmon; R.E. Tucker and W.E.C. Moor (1970): Studies of processing nutritional value and palatability of broiler litter for ruminants.

- Pro Internat. Sym on Livstock wastes. ASAE Pub. Proc. 271-301.

Fontentot, J.P. and K.E. Webb, Jr. (1974): Poultry wastes as feedstuffs for ruminants Fed Proc. 33 (8): 1936-1937.

Fontenat, J.P. and K.E. Webb, Jr. (1975): Health aspects fo recycling animal wastes by feeding. J. Anim. Sci., 40(6): 1267-77.

Lovett, J.; J.W. Messer and R.B. Read, Jr. (1971): The microflora of the Southern Ohio poultry Litter Poult. Sci., 50: 746.

McCaskey, T.A. and W.B. Anthony (1979): Human and animal health aspects of feeding Livestock excreta. J. Anim. Sci., 48(1): 163-177.

Nilo, L. and R.J. Avery (1965): Bovine Enterotoxemia "l clostridium perfrengens types isolated from animal sources in Alberta and Saskatchewan. Condian Vet. J., 4: 31.

Noland, P.R.; B.F. Ford and M.L. Ray (1955): The use of ground chicken litter as a source of nitrogen for gastating-Lactating ewes and fattening stears. J. Anim. Sci., 14: 866.

U.S.D.A. (1957): Animal disease, the year book of agriculture (1956): U.S. Government printing office Washington D.C.

Schefferete, H.E. (1965 a): The decompositionof uric acid in built up poultry litter. J. Appl. Boc., 28: 412.

Schefferete, H.E. (1965 b): The microbiology of built up poultry litter. J. Appl. Boc., 28: $401-403$.

Schwabe, C.W. (1964): Veterinary Medicine and human health the Williams and Wilkins Co, Baltimore, Hd.

Smith, H.W. (1955): The longevityof salmonella gallinarium in the faeces of infected chicken J. Comp. Path., 65: 267.

Smith, L.W.; H.K. Goering and C.H. Gordon (1969): Influence of chemical treatment upon digestibility of ruminant faeces. Proc. of the conf on animal waste Mgmt connell Univ. Ithaca, N Y Jan. 1969, p. 88-97.

Strauch, D. and W. Mutller (1968): Salmonella bacteria survival time at different temperature when placed in faeces from battery fowl. Tierserztl Wochseher. 81:468.

Wilson, G.S. and A.A. Mites (1964): Topley and Wilsons principles of bacteriology and immunity (5th Ed.). Edward Arnold Publishers Itd London.

Assiut Vet.Med.J. Vol. 22, No. 43,1989. 


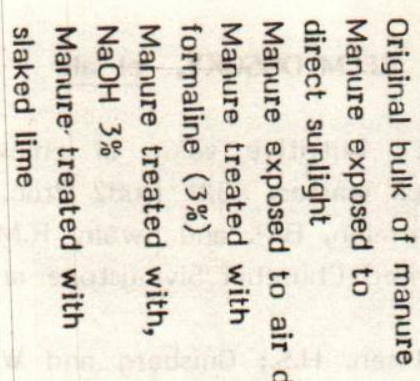

है

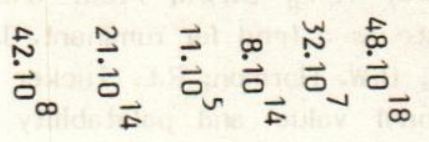

市

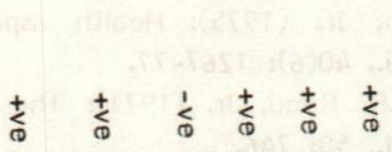

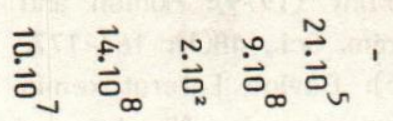

交

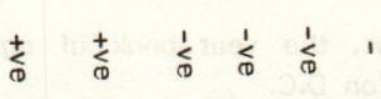

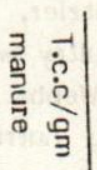

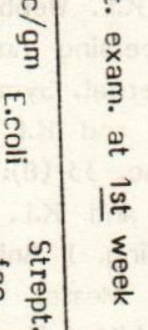

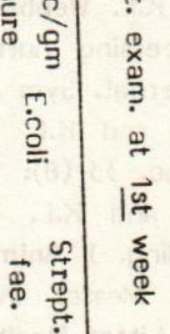

峁

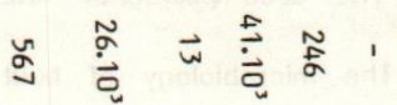

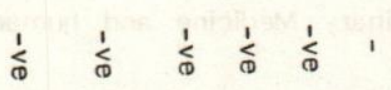

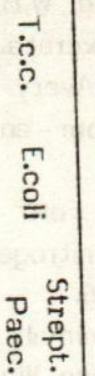

怘

굴

离

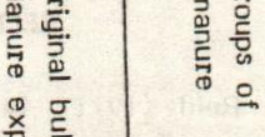

(2)

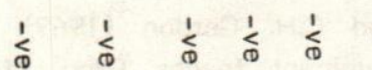

प्ष.ّ.

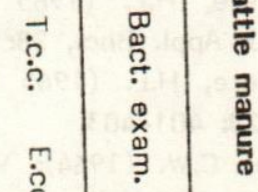




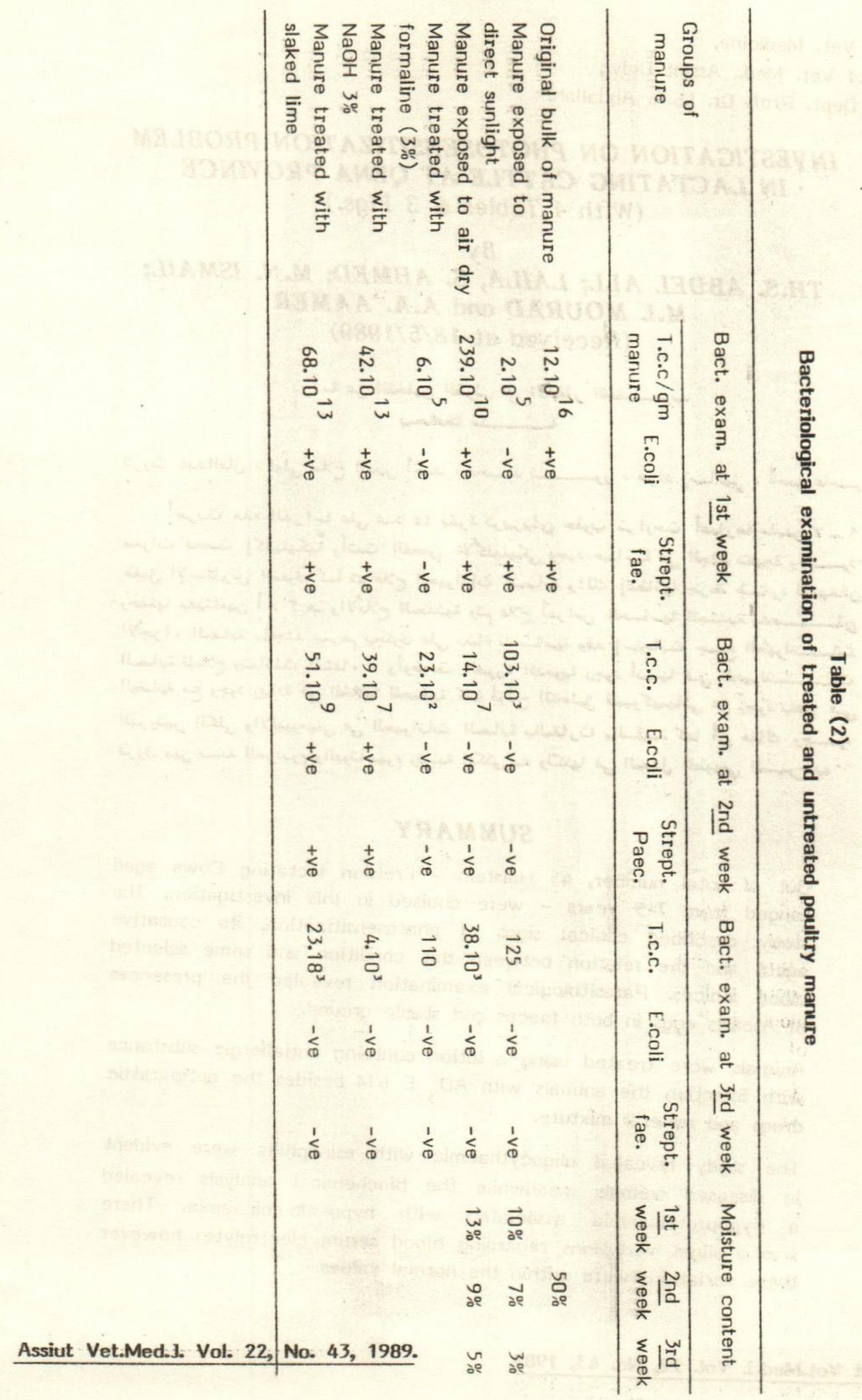

